\title{
Consideration of the Exercise position for Facilitating Gluteus Medius Maximally in Normal Adults
}

\author{
Sung Jin Park', Ji Won Park², Yonghyun Kwon' \\ 'Department of Physical Therapy, Yeungnam University College, Daegu; ${ }^{2}$ Department of Physical Therapy, College of Bio and Medical Science, Daegu \\ Catholic University, Gyeongsan, Korea
}

Purpose: This study examined the most efficient exercise position to activate the gluteus medius (GM) and tensor fascia latae (TFL) in hip abduction in side-lying (HA-SL), clam in side-lying (CL-SL), and sling bridging in side-lying (SB-SL), which are the most representative GM exercises.

Methods: Twenty-four healthy male adults aged from 20 to 40 years, whose body mass index was under 25, participated in this experiment. While all participants conducted three different positions with a counterbalanced manner, such as in $A B, C L$, and $B R$, activation of the GM and TFL was measured using 8-channel wireless EMG. Exercise was performed for 10 seconds three times in total with a five minute-break session.

Results: Significant differences in GM and TFL activation were observed among the three positions $(p<0.05)$. The highest activation of 60.69 was observed in BR followed in order by 46.03 and 12.92 in HA-SL and CL, respectively. TFL activation in HA-SL was 42.01, followed in order by 35.98 and 14.01 in $B R$ and $C L$, respectively. On the other hand, there was no significant difference in TFL muscle activation between $B R$ and HA-SL.

Conclusion: These findings suggest that both BR and HA-SL in GM can be done selectively. CL has remarkably low muscle activation in GM and TFL, which makes it less valuable in GM and TFL exercise. In conclusion, selective BR and HA-SL exercise should be applied to maximally and effectively activate the GM.

Keywords: Gluteus medius, Tensor fascia latae, Exercise position

\section{서 론}

엉덩근의 약화는 상지의 부상, 엉덩정강띠 통증 증후군(patellofemoral pain syndrome), 엉덩정강띠 마찰 증후군(iliotibial band friction syndrome), 요통, 앞십자인대의 염좌 그리고 만성 발목불안정성과 연관 이 있다.1-4 엉덩정강띠 통증 증후군과 장경인대 마찰 증후군은 넙다 리뼈의 내전과 내회전, 무릎의 외반슬과 목말밑관절의 회내를 유발 한다.5.6 엉덩관절 기능 부전과 하지 부상과의 관계는 이미 명백히 문 헌으로 드러났으며, 엉덩관절 근육 강화는 재활 순서의 한 부분으로 써 집중되어졌다.7.9 Granat 등은 입각기 중기에 체중을 지탱할 수 없 기 때문에 골반대를 반대 측으로 기울게 만드는 트렌델렌버그 보행 징후를 보이게 된다고 하였고, ${ }^{10}$ 이로 인한 특정한 움직임의 수행에 어려움을 겪고 방어적 행동으로 자세의 불균형을 초래하게 된다."
중간볼기근은 대표적인 엉덩관절 외전근으로서 골반의 엉덩뼈능 선에서 대퇴골의 큰돌기로 연결되는 부채꼴 모양의 근육으로 엉덩관 절의 외전, 신전, 외회전 동작을 한다. 특히, 중간볼기근은 일차적인 엉덩관절의 외전 역할을 담당하고, 외전근 중에서 가장 큰 근육으로 전체 횡단 면적의 $60 \%$ 를 차지하고 있다. ${ }^{12}$ 이로 인해 많은 연구들이 가장 효과적인 외전 운동을 찾기 위해 일상에서 쉽게 접할 수 있는 운동이나 그 운동 방법의 단점을 보완할 수 있는 응용 동작을 만들 기 위해 노력하였고, 또한 어떤 운동이 가장 효과적으로 중간볼기근 을 활성화 시킬 수 있는지에 대해 연구하였다.13-15 특히 Distefano 등16 과 Selkowitz 등 17 은 각각 11 가지, 12 가지 중간볼기근 활성화 운동 중 옆으로 누운 자세에서 엉덩관절 외전운동(hip abduction in side-lying, $\mathrm{HA}-\mathrm{SL})$ 이 가장 많은 활성화가 나타난다고 보고하였으며, Jang ${ }^{18}$ 은 클 램운동(clam exercise in side-lying, CL-SL)이 중간볼기근 활성에 가장
Received Feb 12, 2019 Revised Feb 17, 2019

Accepted Feb 28, 2019

Corresponding author Yonghyun Kwon

E-mail yhkwon@ync.ac.kr
Copylight (C)2019 The Korean Society of Physical Therapy

This is an Open Access article distribute under the terms of the Creative Commons Attribution Non-commercial License (Http:// creativecommons.org/license/by-nc/4.o.) which permits unrestricted non-commercial use, distribution, and reproduction in any medium, provided the original work is properly cited. 
효과적인 운동이라 하였다. 또한 Chun ${ }^{19}$ 은 슬링을 이용한 교각운동 (sling-bridging in side-lying, SB-SL)이 효과적이라고 하였다. 그러나 선 행연구들은 엉덩관절의 외전운동에서의 응용 동작으로만 실험을 하 였을 뿐 다른 운동과의 비교 및 분석 연구는 이루어지지 않았다.

이러한 선행연구들의 한계점은 다양한 치료적 운동프로그램을 수 행하면서 중간볼기근의 근활성도는 측정하였지만, 중간볼기근의 힘 을 강력히 돕는 넙다리근막긴장근의 활성도를 제외하지 않은 상황 에서 연구가 되었을 가능성이 있다. 이는 중간볼기근이 제 기능을 하 지 못한다면 자연스럽게 넙다리근막긴장근에 작용이 더 많은 역할 을 할 것이며, 중간볼기근 운동의 효율성을 떨어뜨릴 것이다.

넙다리근막긴장근은 엉덩관절의 외전과 내회전으로 작용하는데, 슬개골과 슬개지대를 연결하는 엉덩정강띠를 활성화시켜 슬개골을 외측으로 당기는 역할을 한다. ${ }^{20}$ 과도한 엉덩관절 내회전과 슬개골 외 측 전이는 엉덩정강띠 통증 증후군과 같은 질병으로 이어질 수도 있 다. ${ }^{21,22}$ 특히 넙다리근막긴장근은 엉덩관절 외전 시에 넙다리근막긴 장근이 습관적으로 과활성화되며, 결과적으로 중간볼기근의 외회전 기능을 하는 뒤쪽 섬유를 약화시키거나 위축을 유발할 수 있다. ${ }^{23}$ 그 러므로 넙다리근막긴장근의 활성도가 없는 상태에서 중간볼기근의 활성 정도를 확인할 수 있는 실험 설계가 필요하다. 이러한 문제점을 보완하기 위해 Selkowitz 등17은 중간볼기근과 넙다리근막긴장근의 근활성도를 비율로 측정하여 가장 효율적인 중간볼기근 운동이 무 엇인지를 11 가지의 운동 설계를 통하여 증명하였다.

따라서 본 연구는 중간볼기근 수축의 대표적인 운동인 HA-SL운 동, CL-SL운동, SB-SL운동을 선별하여, 넙다리근막긴장근을 고려한 중간볼기근에 어떤 운동 방법이 가장 효과적인지를 연구하였다.

\section{연구 방법}

\section{1. 연구대상}

본 연구는 20 대 및 30 대의 24 명의 정상 성인을 대상으로 하였다. 대상 자들은 근골격계 질환 및 관련된 통증, 신경학적 증세가 없는 자, 신 체질량지수(body mass index, BMI)가 25 이하인 대상자만 선별하였 다. 실험 전에 실험자가 피실험자에게 연구에 대해서 자세하게 설명 하였으며, 실험 참가동의서에 동의를 받은 후 실험을 실시하였다.

\section{2. 실험방법}

1) 엉덩관절 외전 운동방법

대상자들은 세 가지 종류의 엉덩관절 외전 운동 방법인 옆으로 누운 자세에서 엉덩관절 외전운동(HA-SL), 옆으로 누운 자세에서 클램운 동(CL-SL), 옆으로 누운 자세에서 슬링 교각운동(SB-SL)을 실시하였 다. ${ }^{1724} \mathrm{HA}-\mathrm{SL}$ 운동은 옆으로 누운 자세에서 엉덩관절이 수평면의 수 직 방향으로 중력에 대항하여 $30^{\circ}$ 까지 외전하도록 실시하였다. CL-SL 운동은 옆으로 누운 자세에서 엉덩관절과 무릎관절을 $90^{\circ}$ 로 굴곡한 자세에서 엉덩관절이 수평면의 수직 방향으로 중력에 대항하여 $30^{\circ}$ 까지 외전하도록 하였다. SB-SL운동은 슬링을 이용하여 옆으로 누운 자세에서 슬링의 밴드가 발목관절의 위쪽에 오도록 하고 대상자의 골반을 수평면의 수직 방향으로 중력에 대항하여 바닥에서 들어 올 리도록 하였다(Table 1).

운동의 순서는 상호교차법(counterbalanced manner) 순으로 실시 하였고, 각각의 운동 방법에서 10 초간 운동하는 방법으로 총 3 회 실 시하였다. 근전도의 정확한 자료 분석을 위해 초기와 후기 각 3 초 동 안수집한 자료는 분석에서 제외하였고, 중간 범위의 4 초간의 근활성 도를 분석하였다. 근피로의 방지를 위해 각 운동 방법의 1 회마다 30

Table 1. Maximal voluntary isometric contraction of gluteus medius and tensor fascia latae during three types of exercise positions

\begin{tabular}{lccccc}
\hline & $\mathrm{HA}-\mathrm{SL}$ & $\mathrm{CL}-\mathrm{SL}$ & $\mathrm{SB}-\mathrm{SL}$ & $\mathrm{F}$ & $\mathrm{p}$ \\
\hline Gluteus medius & $46.03 \pm 0.24$ & $12.92 \pm 0.13$ & $60.69 \pm 0.60$ & 86.14 & 0.00 \\
Tensor fascia latae & $42.01 \pm 0.42$ & $14.01 \pm 0.14$ & $35.98 \pm 0.36$ & 12.61 & 0.00 \\
\hline
\end{tabular}

Value of MVIC are means \pm standard deviation.

HA-SL: hip abduction in side lying, CL-SL: clam in side lying, SB-SL: sling bridging in side lying.
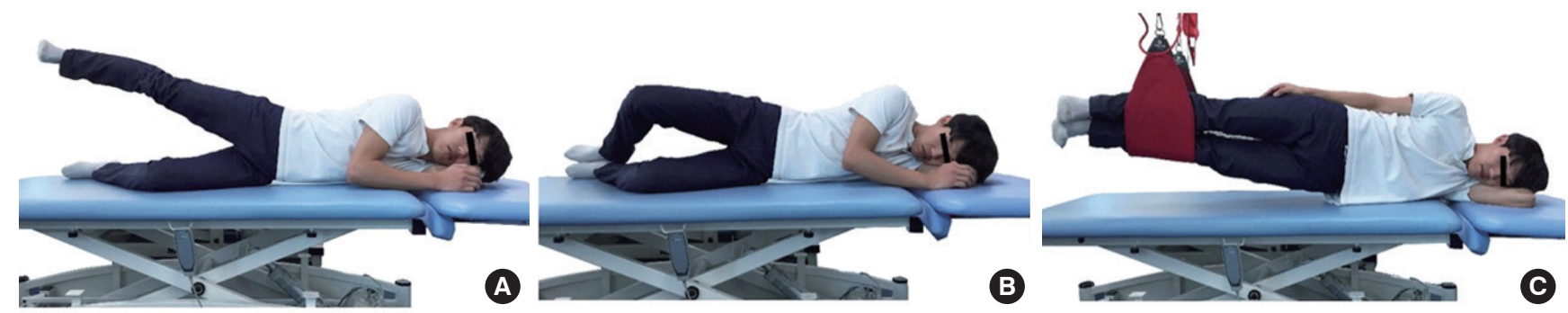

Figure 1. Three types of exercise positions. (A) Hip abduction in side-lying, (B) Clam in side-lying, (C) Sling bridging in side-lying. 
초간의 휴식 시간을 주었으며, 한 가지의 운동 방법이 끝나고 다음 운 동을 적용할 때, 5 분간의 휴식을 제공하였다. 각 운동 방법의 자세는 Figure 1과같다.

\section{2) 근전도 전극부착}

양하지 중에 우세측 다리를 측정 부위로 하였으며 전극을 붙이기 전 에 알코올로 소독한 후, 면도칼로 제모하였다. 중간볼기근의 활성화 는 8채널 무선 근전도 장비(WEMG-8, Laxtha, 한국)를 사용하였고 전 극은 중간볼기근과 넙다리근막긴장근에 부착하였다. 특히 중간볼기 근 중간섬유의 전극 배치는 엉덩뼈능선 최고점의 중간부위 $2.5 \mathrm{~cm}$ 밑 에 부착하였다. 넙다리근막긴장근 전극은 전상장골극의 약간 바깥 쪽과 밑, 그리고 대퇴골 큰돌기의 위쪽과 안쪽으로 부착하였고, 제3 전극은 7 번째 경추 극돌기에 부착하였다.

\section{3) 근전도 신호의 기록 및 처리}

근육의 근전도 신호를 측정하기 위하여 임의의 근육을 선택하고 5 초 동안 3 번 측정하여 최대 등척성 수축(maximum voluntary isometric contractions, MVIC)을 사용하였다. 정량적인 비교 분석을 위하여 최 대 등척성 수축 시 5 초간의 측정값을 구한 후, 초기와 후기 각 1 초 제 외한 3 초 동안의 평균 근전도 신호량을 최대 등척성 수축으로 사용 하였고, 측정값의 표준 근전도 신호량을 부석에 사용하였다. 최대 등 척성 수축을 위한 맨손근력검사는 가장 보편화된 Hislop의 적용 방 법을 적용하였다..$^{25}$ 근전도 신호의 표본추출은 $1,024 \mathrm{~Hz}$, 대역통과필 터는 20-450 Hz를 설정하였다.

\section{3. 통계 분석}

중간볼기근과 넙다리근막긴장근의 3 가지의 운동에 따른 상대적 근

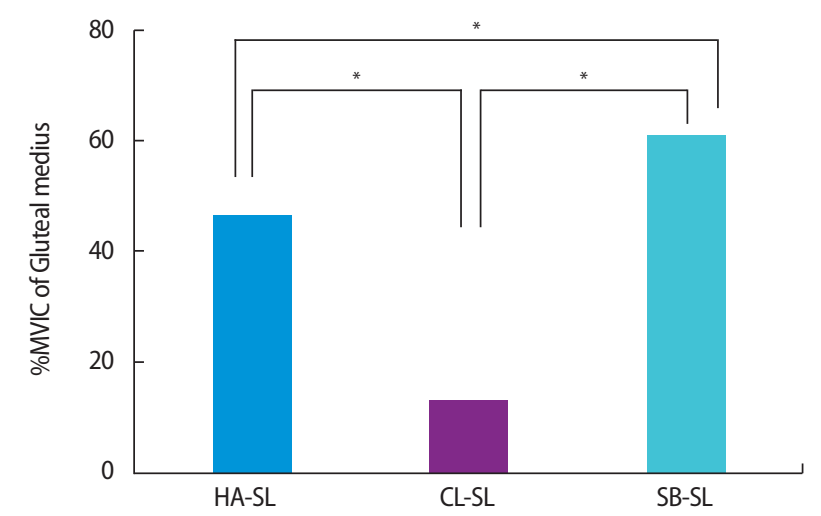

Figure 2. Results of maximal voluntary isometric contraction of gluteal medius in the three types of exercises.

HA-SL: hip abduction in side lying, CL-SL: clam in side lying, SB-SL: sling bridging in side lying. ${ }^{*} \mathrm{p}<0.05$.
활성도 차이를 알아보기 위하여 반복측정 분산분석법(repeated $\mathrm{ANOVA)}$ 을 사용하였다. 각 운동 간의 통계적 유의성에 대한 사후 검 정으로 Bonferonni를 사용하여 신뢰도를 검정하였고, 유의수준은 $a$ $<0.05$ 로 설정하였다. 수집된 자료는 상용화된 통계 프로그램인 윈도 우용 SPSS (PASW statistics) version 18.0을 사용하였다.

\section{결 과}

대상자의 일반적 특성으로 나이는 23세에서 39세를 보였으며, 몸무 게는 $60 \mathrm{~kg}$ 에서 $81 \mathrm{~kg}$ 의 범위로 나타났다. 키는 $168 \mathrm{~cm}$ 에서 $182 \mathrm{~cm}$ 로 나타났고, 신체질량지수는 21.26에서 24.45의 범위를 보였다.

3 가지 운동에 따른 중간볼기근의 근활성도는 HA-SL 운동에서는 $60.69 \pm 0.60$ 로써 가장 높게 나타났으며, HA-SL 운동에서는 $46.03 \pm$ 0.24 이었고, CL-SL 운동에서는 $12.92 \pm 0.13$ 으로 가장 낮은 근활성도 를 보였다. 반복 측정에 따른 일원분산에서는 모두 유의한 차이를 나 타내었으며 $(\mathrm{p}<0.05), \mathrm{F}-$ Value 는 86.14로 나타났다. 사후검정으로 중간 볼기근 근육에서 각 운동 간 비교에도 모두 유의한 차이가 있었다 $(\mathrm{p}<0.05)($ Table 1$)$.

넙다리근막긴장근의 근활성도는 HA-SL 운동에서 $42.01 \pm 0.42$ 로 근활성도가 가장 높았으며, BR 운동에서는 $35.98 \pm 0.36$ 이었으며, CL$\mathrm{SL}$ 운동에서는 $14.01 \pm 0.14$ 로써 근활성도가 가장 낮은 수치였다. 반복 측정에 따른 일원분산에서는 모두 유의한 차이를 나타내었으며 $(\mathrm{p}<0.00)$, F-value 는 12.61로 나타났다. 사후검정으로 넙다리근막긴장 근에서 각 운동 간 비교한 경우 HA-SL과 CL-SL, CL-SL과 SB-SL관계 에서는 유의한 차이가 있었지만 $(\mathrm{p}<0.05), \mathrm{HA}-\mathrm{SL}$ 과 SB-SL 사이에서 유의한차이가 나타나지 않았다( $\mathrm{p}>1.00)($ Table 1).

GM to TFL Index $(\mathrm{GTI})$ 는 각 운동 자세에 대한 중간볼기근의 상대 적 근활성 효율성을 보기 위한 것으로, 중간볼기근과 넙다리근막긴 장근의 근활성도 지수의 합을 중간볼기근의 활성화 정도로 나누어 나타낸 값이다. ${ }^{17} \mathrm{GTI}$ 수치는 1 에 가까울수록 그 효율성이 높은 것으 로, SB-SL에서 1.59, HA-SL은 1.91로, 그리고 CL-SL은 2.08로 나타났다.

\section{고 찰}

본 연구에서는 중간볼기근의 안정화 개선을 위하여 중간볼기근 운 동의 가장 대표적인 세 가지 운동인 HA-SL, CL-SL, SB-SL을 실시하였 다. 그 결과 운동군 간의 근활성도는 중간볼기근과 넙다리근막긴장 근 모두 유의한 차이가 있었다. 중간볼기근에서는 SB-SL, HA-SL, CL$\mathrm{SL}$ 순으로 근활성도가 나타났고, 넙다리근막긴장근에서는 HA-SL, SB-SL, CL-SL 순으로 근활성도가 높게 나타났다. HA-SL과 SB-SL운동 에서의 최대 등척성 수축은 중간볼기근이 넙다리근막긴장근보다 
GTI 지수가 높았지만, CL-SL 운동에서는 오히려 넙다리근막긴장근 이 중간볼기근보다 근활성도가 높게 측정되었다. 이는 CL-SL가 상대 적으로 다른 운동에 비해 중간볼기근에서의 근활성 효율성이 떨어 지는 운동이라 판단할수 있다.

각 운동 간의 유의성을 비교하였을 경우, 중간볼기근에서 모두 유 의한 차이가 있었다. 넙다리근막긴장근 활성도에서는 HA-SL, CL-SL, CL-SL에서는 유의한 차이가 존재하였다. 그러나 HA-SL과 SB-SL 사이 엔 유의한 차이가 나지 않았다. 이는 중간볼기근의 선택적 운동이 가 능하기 때문이라고 여겨지며, 이는 HA-SL 과 SB-SL 두 자세에서의 운 동 모두 중간볼기근의 활성화에 효율적이라고 생각된다. Selkowitz 등 ${ }^{17}$ 은 11 가지 운동 중 중간볼기근 활성화는 HA-SL의 자세에서 가장 활 성화가 가장 높다고 하였으며, Distefano 등16과 Bolgla 등 ${ }^{30}$ 의 유사한 실험 결과를 제시하여 이러한 가설을 뒷받침한다.

안정화란 사람이 의식적 또는 무의식적으로 관절에서의 큰 또는 미세한 움직임을 조절할 수 있는 능력이다. 정상보행에서의 중간볼기 근 역할은 감속기에서 시작되고 단일 입각기인 입각 중기에 최대에 이르며 닫힌사슬운동에서 엉덩관절은 $5^{\circ}$ 내전된다. 또한 유각기쪽으 로 골반이 떨어지는 것을 제한하거나 감속하기 위하여 원심성으로 수축한다. ${ }^{26}$ 중간볼기근의 안정화가 확보되지 않으면 옆으로 누운 자 세에서 엉덩관절 외전 시 요방형근의 과도한 사용과 빠른 수축으로 골반이 외측경사되는 보상작용이 발생하여 요통이 유발될 수 있 다. 27,28 Konradsen 등 29 은 발목의 불안정성으로 인한 반복적인 손상을 예방하기 위해서는 볼기근의 움직임에 대한 기능 조절이 중요하며, 발목관절 불안정의 치료 시 고려해 보아야 한다고 그 중요성을 강조 하였다.

근력의 증가는 근수축이 최대 등척성 수축의 $40-70 \%$ 이상에서 가 능하다고 보고되어있다. ${ }^{31}$ 그러나 CL-SL은 최대 등척성 수축 수치가 너무 낮아중간볼기근 운동에 적합한 운동이라 할 수 없으며, 또한 넙 다리근막긴장근의 근력 증가에서도 동일하다. 이는 중간볼기근의 후 방섬유는 엉덩관절의 신전, 외전 및 외회전에 주동적으로 작용하고, 과사용 등과 같은 다양한 원인에 의해 과도하게 신장되거나 약해지 기 쉽다.28 이를 보상하기 위해 중간볼기근의 뒤쪽 부분을 자극하기 위해서 엉덩관절 굴곡과 외회전의 모먼트암(moment arm) 자세를 취 하는 것이 오히려 부작용으로 작용되어, 대둔근과 심부 엉덩관절 외 회전근로서의 역할을 수행하는 결과를 초래하였다고 보고되었다. ${ }^{32}$ Boren 등 ${ }^{33}$ 은 CL-SL 자세에서 중간볼기근의 활성화에 많은 영향을 주 지 않는다고 보고하였을 뿐만 아니라, 오히려 CL-SL 자세에서의 변형 동작이 중간볼기근의 활성화에 더 좋은 결과를 가져온다고 보고하 였다. 또한 Selkowitz 등근 CL-SL 자세에서는 중간볼기근 보다 큰볼 기근에서 활성화가 크다고 보고하였다. Soderburg와 Dostal ${ }^{22}$ 은 체간 굴곡, 한 발로 서 있기, 계단을 오르거나 쪼그려 앉기 등의 일상적인
생활에서도 중간볼기근의 근 활성도가 증가한다고 보고하였다. 또한 중간볼기근의 안정성은 대상자가 수동적인 아닌 자신이 스스로 필요 한 근육에 근력을 향상시키기 위한 능동적인 운동을 통해야만 획득 될 수 있다. 본 연구결과에 따르면, 능동적 중간볼기근 운동에 넙다리 근막긴장근을 제외한 가장 효율적인 자세 및 치료적 방법은 SB-SL 운 동이라 보여진다.

본 연구 결과는 정상 성인에 국한되며, 엉덩관절의 기능 이상이 있 는 환자에게 적용하기에 한계점이 있고 심부 근육을 측정할 수 없는 표면 근전도의 제한점으로 인해 총체적인 근육군들의 분석이 현실 적으로 불가능한 단점이 있었다. 본 연구는 가장 대표적 중간볼기근 운동인 HA-SL, CL-SL, SB-SL 중에서 넙다리근막긴장근을 제외한 가 장 효과적인 중간볼기근 운동을 상대적으로 실험하고 비교하고자 하였다. 그 결과 상대적으로 가장 효율이 뛰어난 운동은 SB-SL이었으 며, HA-SL 운동 또한 효율적이라는 것을 확인할 수 있었다. 따라서 이 러한 연구결과는 중간볼기근의 근력을 강화시킬 수 있는 치료적 접 근에 관한 유용한 자료가 될 것으로 생각한다.

\section{REFERENCES}

1. Cichanowski HR, Schmitt JS, Johnson RJ et al. Hip strength in collegiate female athletes with patellofemoral pain. Med Sci Sports Exerc. 2007; 39(8):1227-32.

2. Friel K, McLean N, Myers C et al. Ipsilateral hip abductor weakness after inversion ankle sprain. J Athl Train. 2006;41(1):74-8.

3. Hewett TE, Myer GD, Ford KR. Anterior cruciate ligament injuries in female athletes: Part 1, mechanisms and risk factors. Am J Sports Med. 2006;34(2):299-311.

4. Robinson RL, Nee RJ. Analysis of hip strength in females seeking physical therapy treatment for unilateral patellofemoral pain syndrome. J Orthop Sports Phys Ther. 2007;37(5):232-8.

5. Ford KR, Myer GD, Toms HE et al. Gender differences in the kinematics of unanticipated cutting in young athletes. Med Sci Sports Exerc. 2005; 37(1):124-9.

6. Fredericson M, Cookingham CL, Chaudhari AM et al. Hip abductor weakness in distance runners with iliotibial band syndrome. Clin J Sport Med. 2000;10(3):169-75.

7. Earl JE, Hoch AZ. A proximal strengthening program improves pain, function, and biomechanics in women with patellofemoral pain syndrome. Am J Sports Med. 2011;39(1):154-63.

8. Fukuda TY, Rossetto FM, Magalhaes E et al. Short-term effects of hip abductors and lateral rotators strengthening in females with patellofemoral pain syndrome: a randomized controlled clinical trial. J Orthop Sports Phys Ther. 2010;40(11):736-42.

9. Wagner T, Behnia N, Ancheta WK et al. Strengthening and neuromuscular reeducation of the gluteus maximus in a triathlete with exercise-associated cramping of the hamstrings. J Orthop Sports Phys Ther. 2010; 40(2):112-9.

10. Granat MH, Maxwell DJ, Ferguson AC et al. Peroneal stimulator; evalu- 
ation for the correction of spastic drop foot in hemiplegia. Arch Phys Med Rehabil. 1996;77(1):19-24.

11. Lebangie PK, Norkin CC. Joint structure and function: A comprehensive analysis. 5th, Philadelphia, F.A. Davis Company, 2011.

12. Clark JM, Haynor DR. Anatomy of the abductor muscles of the hip as studied by computed tomography. J Bone Joint Surg Am. 1987;69(7): 1021-31.

13. Boudreau SN, Dwyer MK, Mattacola CG et al. Hip-muscle activation during the lunge, single-leg squat, and step-up-and-over exercises. J Sport Rehabil. 2009;18(1):91-103.

14. Ekstrom RA, Donatelli RA, Carp KC. Electromyographic analysis of core trunk, hip, and thigh muscles during 9 rehabilitation exercises. J Orthop Sports Phys Ther. 2007;37(12):754-62.

15. McBeth JM, Earl-Boehm JE, Cobb SC et al. Hip muscle activity during 3 side-lying hip-strengthening exercises in distance runners. J Athl Train. 2012;47(1):15-23.

16. Distefano LJ, Blackburn JT, Marshall SW et al. Gluteal muscle activation during common therapeutic exercises. J Orthop Sports Phys Ther. 2009;39(7):532-40.

17. Selkowitz DM, Beneck GJ, Powers CM. Which exercises target the gluteal muscles while minimizing activation of the tensor fascia lata? Electromyographic assessment using fine-wire electrodes. J Orthop Sports Phys Ther. 2013;43(2):54-64.

18. Jang PH. Electromyographic analysis of gluteus medius and gluteus maximus during 20 exercises. Dankook University, Dissertation of Master's degree. 2015.

19. Chun DC. Comparison of gluteus medius activity according to the posture of hip abduction exercise. Daegu Catholic University, Dissertation of Master's degree. 2014.

20. Kwak SD, Ahmad CS, Gardner TR et al. Hamstrings and iliotibial band forces affect knee kinematics and contact pattern. J Orthop Res. 2000;18(1):101-8.

21. Powers CM. The influence of abnormal hip mechanics on knee injury:
A biomechanical perspective. J Orthop Sports Phys Ther. 2010;40(2):4251.

22. Soderberg GL, Dostal WF. Electromyographic study of three parts of the gluteus medius muscle during functional activities. Phys Ther. 1978; 58(6):691-6.

23. Gombatto SP, Norton BJ, Sahrmann SA et al. Factors contributing to lumbar region passive tissue characteristics in people with and people without low back pain. Clin Biomech (Bristol, Avon). 2013;28(3):25561.

24. Widler KS, Glatthorn JF, Bizzini M et al. Assessment of hip abductor muscle strength. A validity and reliability study. J Bone Joint Surg Am. 2009;91(11):2666-72.

25. Avers D, Brown M, Hislop H. Daniels and worthingham's muscle testing. 9th. Saunders, Elsevier Health Sciences, 2013.

26. Houglum PA, Bertoti DB. Brunnstrom's clinical kinesiology. 6th. Philadelphia F.A. Davis Company, 2012.

27. Chaitow L, Crenshaw K. Muscle energy techniques. 3th, London, Elsevier Churchill Livingstone, 2006.

28. Sahrmann S. Diagnosis and treatment of movement impairment syndromes. 1st. St Louis, Mosby, 2001.

29. Konradsen L, Voigt M, Hojsgaard C. Ankle inversion injuries. The role of the dynamic defense mechanism. Am J Sports Med. 1997;25(1):54-8.

30. Bolgla LA, Malone TR, Umberger BR et al. Comparison of hip and knee strength and neuromuscular activity in subjects with and without patellofemoral pain syndrome. Int J Sports Phys Ther. 2011;6(4):285-96.

31. Andersen LL, Magnusson SP, Nielsen M et al. Neuromuscular activation in conventional therapeutic exercises and heavy resistance exercises: implications for rehabilitation. Phys Ther. 2006;86(5):683-97.

32. Delp SL, Hess WE, Hungerford DS et al. Variation of rotation moment arms with hip flexion. J Biomech. 1999;32(5):493-501.

33. Boren K, Conrey C, Le Coguic J et al. Electromyographic analysis of gluteus medius and gluteus maximus during rehabilitation exercises. Int J Sports Phys Ther. 2011;6(3):206-23. 